\title{
Kişilik Özellikleri, Mizah Tarzları ve Üniversiteye Uyum Arasındaki Doğrudan ve Dolaylı İlişkiler: Mizah Tarzlarının Aracı Rolü
}

\section{Direct and Indirect Relationships Between Personality Characteristics, Humor Styles and University Adjustment: The Mediating Role of Humor Styles}

\author{
Ömer Taha Sözer ${ }^{1}$ (D), Sinem Öztürk Dursun² ${ }^{\mathbb{D}}$, Neslihan Yortan² (D), Ülkü Güreşen ${ }^{3}$ (D), \\ Mehmet Şakiroğlu ${ }^{4}$ (D)
}

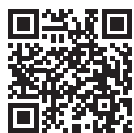

Yazar notu: Bu araștırma II. Uluslararası Gençlik Araștırmaları Kongresi'nde sözlü bildiri olarak sunulmuştur.

'Arş. Gör., Adnan Menderes Üniversitesi, FenEdebiyat Fakültesi, Psikoloji Bölümü, Aydın, Türkiye

${ }^{2}$ Arş. Gör., İzmir Katip Çelebi Üniversitesi, İzmir Katip Çelebi Üniversitesi, Sosyal ve Beşeri Bilimler Fakültesi Psikoloji Bölümü, İzmir, Türkiye ${ }^{3}$ Uzm. Psikolog, Aydın Devlet Hastanesi, Aydın, Türkiye

Türkiye
${ }^{4}$ Dr. Öğr. Üyesi, Adnan Menderes Üniversitesi,

Fen-Edebiyat Fakültesi, Psikoloji Bölümü, Aydın, Türkiye

ORCID: Ö.T.S. 0000-0001-8955-3194; S.Ö.D. $0000-0002-2176-8727$

N.Y. $0000-0003-3815-4905$

U.Y. 0000-0003-3815-4905;

Ü.G. 0000-0002-2505-4094;
M.SS. 0000-0001-8990-621X

Sorumlu yazar/Corresponding author: Ömer Taha Sözer,

Adnan Menderes Üniversitesi, Fen-Edebiyat Fakültesi, Psikoloji Bölümü, Aydın, Türkiye

E-posta/E-mail: o.sozer@adu.edu.tr

Başvuru/Submitted: 04.07.2019 Revizyon Talebi/Revision Requested: 09.07.2019

Son Revizyon/Last Revision Received: 15.04.2020

Kabul/Accepted: 11.06 .2020

Online Yayın/Published Online: 18.11 .2020

Atıf/Citation: Sozer, O. T., Ozturk Dursun, S., Yortan, N., Guresen, U. ve Sakiroglu, M. (2020). Kişilik özellikleri, mizah tarzları ve üniversiteye uyum arasındaki doğrudan ve dolaylı iliskiler: Mizah tarzlarının agu rö. Psikolojiçalısmala - Studies in Psychology, 40(2): 533-559. - Studies in Psychology, 40(2): 533-559.
https://doi.org/10.26650/SP2019-0047
ÖZ

Üniversite uyumu, üniversiteye yeni başlayan gençlerin en sık karşılaştıkları yaşam zorlukları arasındadır. Uyum sürecini olumlu ya da olumsuz etkileyebilecek çeşitli bireysel farklılıklar olabilir. Bu farklılıkların ve uyumu kolaylaştırabilecek değişkenlerin belirlenmesi öğrencilerin yaşayabilecekleri zorlukların anlaşılması açısından önemli olacaktır ve erken müdahale imkanı sunacaktır. Buradan hareketle bu çalışma üniversiteye uyumda kişilik özelliklerinin ve mizah tarzlarının doğrudan etkisini ve kişilik özellikleri ile üniversiteye uyum arasındaki ilişkide mizah tarzlarının dolaylı etkisini incelemeyi amaçlamaktadır. Kişilik özellikleri Pekiştirmeye Duyarlılık Kuramı doğrultusunda önerilen davranışsal aktivasyon ve davranışsal inhibisyon sistemleri referans alınarak değerlendirilmiştir. Mizah tarzları ise kendini geliştirici, kendini yıkıcı, katılımcı ve saldırgan mizah olarak dört farklı boyutta ele alınmıştır. Türkiye'deki bir devlet üniversitesinde birinci sınıf okuyan 282 öğrenci araştırmaya dahil edilmiştir. Katılımcıların 193'ü kadın, 87'si erkektir. Araştırmada Davranışsal Aktivasyon-İnhibisyon Ölçeği, Mizah Tarzları Ölçeği ve Üniversite Yaşamı Ölçeği kağıt-kalem formu olarak uygulanmıştır. Bulgular davranışsal inhibisyonun üniversiteye uyumu negatif, davranışsal aktivasyonun ise üniversiteye uyumu pozitif yönde yordadığını göstermiştir. Ayrıca kendini yıkıcı mizah tarzının üniversiteye uyumu negatif, kendini geliştirici ve katılımcı mizahın ise üniversiteye uyumu pozitif yönde yordadığı saptanmıştır. Yürütülen aracılık analizleri sonuçlarına göre davranışsal aktivasyon ile üniversiteye uyum arasındaki ilişkide kendini geliştirici ve katılımcı mizah tarzlarının kısmi aracı oldukları saptanmışıı. Ayrıca davranışsal inhibisyon ile üniversiteye uyum arasındaki ilişkide kendini yıkıcı mizahın aracı rolü incelenmiş, ancak analiz sonuçları kendini yıkıcı mizah tarzının aracı rolü olmadığını göstermiştir. Sonuçlara göre DíS ve kendini yerici mizah tarzı üniversite uyumu açısından risk faktörleri olarak değerlendirilebilirken DAS, kendini geliştirici ve katılımcı mizah tarzları uyum sürecini kolaylaştırabilir. Ödül duyarlılığı yüksek öğrenciler üniversiteye uyum sağlarken olumlu mizah tarzlarını kullanmakla birlikte, ceza duyarlılığı yüksek öğrencilerin uyum sürecinde yaşadıkları güçlüklerde olumsuz mizah tarzının rolü bulunmamaktadır. $\mathrm{Bu}$ sebeple bazı kişilik özelliklerinin üniversite uyumu için risk oluşturabileceğinin farkında olunmasının ve bir baş etme yöntemi olarak olumlu mizah tarzlarının geliştirilmesinin uyum sürecine katkıda bulunabileceği düşünülmektedir. Anahtar Kelimeler: Üniversite uyumu, mizah, davranışsal aktivasyon, davranışsal inhibisyon, kişilik, baş etme 


\section{ABSTRACT}

University adjustment is one of the most common life challenges that freshman encounter. There may be several individual differences that can either positively or negatively affect the adjustment process. Identifying the individual differences and variables that facilitate the adjustment process is significant to an understanding of students' adjustment difficulties and to hereby providing the opportunity for early intervention. For this reason, this study aims to investigate the direct effect of personality and humor styles on university adjustment and the indirect effect of humor styles on the relationship between personality and university adjustment. Behavioral activation and behavioral inhibition systems, postulated by Reinforcement Sensitivity Theory, were taken as a reference to measure personality characteristics. Humor styles were categorized in four different dimensions; self-enhancing, affiliative, self-defeating, and aggressive humor. Participants were 282 freshman students from a public university in Turkey. Of the participants 193 were female and 87 were male. Behavioral Activation-Inhibition Scale, Humor Styles Scale and University Life Scale were applied using a paper-pencil form. The results showed that while university adjustment was negatively predicted by behavioral inhibition, it was positively predicted by behavioral activation. Also, self-defeating humor predicted university adjustment negatively, while self-enhancing and affiliative humor predicted it positively. The results of the mediation analyses revealed that the relationship between behavioral activation and university adjustment was mediated partially by self-enhancing and affiliative humor styles. The mediational role of self-defeating humor in the relationship between behavioral inhibition and university adjustment was also examined, but the result showed that self-defeating humor had no mediational role. According to the results, BIS and self-defeating humor style seem to be risk factors for university adjustment whereas BAS, self-enhancing and affiliative humor styles facilitate this process. Students high in reward sensitivity use positive humor styles when adjusting to university, whereas difficulties in the adjustment process of students high in punishment sensitivity are not due to the use of malignant humor styles. For this reason, recognizing some personality characteristics as risk factors for university adjustment and enhancing positive humor styles as coping strategies may be helpful for dealing with the adjustment process.

Keywords: University adjustment, humor, behavioral activation, behavioral inhibition, personality, coping

\section{EXTENDED ABSTRACT}

According to Reinforcement Sensitivity Theory, approach and avoidance motivations are two basic biological personality characteristics (Gray, 1982). These motivations are derived from the behavioral activation system (BAS) and the behavioral inhibition system (BIS) in the brain. BAS is activated by the presence of cues for reward and is responsible for positive emotions, whereas BIS is activated by punishing stimuli and is responsible for negative emotions, specifically anxiety and fear. Recent studies show that these two systems are not only related to daily emotions, behaviors and cognitions, but also to pathological conditions such as externalizing and internalizing disturbances (See, Bijttebie, Beck, Claes, \&Vandereycken, 2009).

College adjustment is a highly important issue for students, especially for freshmen. The first year of university life may be challenging for some students, but not all of them adapt to this situation to the same degree. Students' personality may shape the adaptation process via some coping strategies (Carver \& Connor-Smith, 2010). So, in stressful conditions individuals may utilize some coping strategies compatible with their personality. Thus, some strategies may facilitate the adaptation process. 
Coping strategies are a broad concept in the psychology literature but some strategies like humor have not been investigated as much as others. Coping humor was found to be correlated with less stress (Fritz, Russek, \& Dillon, 2017), with less depression (Overholser, 1992) and even with long-term physical health outcomes such as enhanced adjustment to cancer, better physical health and reduced mortality (Romundstad, Svebak, Holen, \& Holmen, 2016).

Humor has been categorized into four distinct styles (Martin, Puhlik-Doris, Larsen, Gray, \& Weir, 2003). Two of them (self-enhancing and affiliative) are beneficial for oneself and for relationships with others, while the other two (self-defeating and aggressive) are harmful in those areas. Self-enhancing humor provides a support for persons even in stressful conditions by maintaining a humorous outlook on life. Affiliative humor is also a benign humor style in that people joke, act and speak in a humorous way to enhance their relationships with others. Self-defeating humor is a harmful humor style in which people disparage themselves to amuse others in order to gain approval or connection. Aggressive humor is used for establishing superiority over others by means of teasing and ridiculing others.

The main purpose of this study is to investigate the direct effect of BAS/BIS and humor styles on university adjustment. Secondly, the study aims to examine the mediating role of humor styles between BAS/BIS and university adjustment.

\section{Method}

The participants in the study were 282 freshman students from a state university in Turkey with the mean age of $19.56(S D=1.36)$, and their ages ranged from 17 to 29 years. 193 of the participants were female (68.5\%) and 87 participants were male (30.9\%). Students were provided with the Turkish version of the BIS/BAS Scale, Humor Styles Questionnaire and University Adjustment Scale. IBM's software SPSS for Windows was used for all analyses. Mediational analyses were conducted by the Model 4 of PROCESS for SPSS (Hayes, 2016).

\section{Results}

The results of the Pearson correlation indicated that both BAS and BIS were associated with university adjustment $(r(280)=.18$ and $r(280)=-.15$, respectively). Of all the humor styles, affiliative humor showed the strongest relation with the outcome $(r(280)=.31)$. Selfenhancing and self-defeating humor were correlated with university adjustment, $(r(280)=$ .18 and $r(280)=-.19$, respectively). Direct effects of personality and humor styles on university adjustment were calculated by multiple linear regression analyses. Results showed that 
the model was significant $\left(R^{2}=.24, F(5,276)=17.82, p<.001\right)$. University adjustment was negatively predicted by behavioral inhibition $(B=-0.72, S E=0.48)$ while it was positively predicted by behavioral activation $(B=0.97, S E=0.40)$. Furthermore, self-defeating humor negatively predicted university adjustment $(B=-1.25, S E=0.22)$ and the two positive humor styles, self-enhancing ( $B=0.77, S E=0.26)$ and affiliative humor $(B=1.43, S E=0.27$ ), positively predicted it. According to the results of the mediational analyses, while both selfenhancing and affiliative humor styles partially mediated the relationship between BAS and university adjustment, self-defeating humor did not mediate the relationship between BIS and university adjustment.

\section{Discussion}

In this study BAS/BIS and humor styles independently predicted university adjustment. According to the results, BIS and self-defeating humor style seem to be risk factors for university adjustment whereas BAS, self-enhancement and affiliative humor styles facilitate this process. Students who are high in reward sensitivity adjust to university partly via using positive humor styles, whereas difficulties in the adjustment process of students who are high in punishment sensitivity are not due to the use of malignant humor styles. In the light of the positive features of humor (Ruch \& McGhee, 2014), incorporating a positive humor style as a coping strategy into counseling or orientation programs may be helpful for students.

Although this study has contributed a new understanding to the adjustment literature, methodological limitations of the study should be taken into consideration in interpreting the results. The cross-sectional nature of this research prevents making inferences about causal relationships. Longitudinal and, in particular, daily diary writing or experience sampling studies would be helpful to understand the humor processes in real life situations and to draw causal inferences regarding adjustment. 
Türkiye İstatistik Kurumu (2019) verilerine göre Türkiye'de her yıl ortalama bir milyondan fazla genç üniversite eğitimine başlamaktadır. Üniversiteye başlayan gençlerin büyük çoğunluğu o güne kadarki yaşamlarını geçirmiş olduğu yeri terk edip başka bir yerde yeni bir yaşama uyum sağlama gibi alışık olmadıkları bir durumla karşılaşmaktadır. İçerisine henüz dahil oldukları bu yaşam biçimi eğitim, insan ilişkileri ve sosyal yaşam açısından geçmiş yaşantılarına göre farklılık göstermektedir (Karahan Sardoğan, Özkamalı ve Dicle, 2005). Dolayısıyla üniversiteye yeni başlayan öğrencilerin karşılaştığı ve üstesinden gelmesi gereken bazı zorluklar vardır. Bu süreçte zorluk yaşayan gençler birtakım psikolojik ve davranışsal problemler gösterebilirler. Gençlerin sorun alanları arasında yalnızlık, aşırı sorumluluk alma, arkadaş ilişkilerinde çatışmalar veya uyumsuzluk, uykuyla ilişkili problemler, akademik ve duygusal sorunlar gösterilmektedir (İkiz ve Otlu, 2015). Üniversite yaşamının getirmiş olduğu birtakım talep ve güçlükleri öğrencilerin ne ölçüde karşılayabildikleri uyumun bir göstergesidir (Feldt, Graham ve Dew, 2011). Öğrencilerin yeni sosyal çevrelerini şekillendirme, üniversitenin yeni bir üyesi olarak üretken olabilme, yeni rolleri ve sorumlulukları üstlenebilme, özerk bir birey olma ve tercih etmiş oldukları alanda ilerleme gibi kriterler üniversiteye uyum sağladıklarının ölçüsü olarak gösterilmektedir (Credé ve Nieohorster, 2012).

Her alanda olduğu gibi üniversiteye uyum sürecinde de birtakım bireysel farklılıklar ortaya çıkmaktadır. Ülkemizde yapılan çalışmalarda iletişim becerileri (Ceyhan, 2006), iyimserliği ve psikolojik dayanıklılığı (Yalım, 2007) yüksek olan öğrencilerin üniversiteye daha iyi uyum sağladığı bulunmuştur. Birtakım problem çözme becerilerinin ve sosyal destek arama eğilimlerinin yanı sıra yalnızlık, kopukluk ve zedelenmiş özerklik gibi erken dönem uyumsuz şemaların (Yıldız, 2018) ve ayrılık anksiyetesinin (Akhunlar Turgut, Sarıot Ertürk, Karslı ve Şakiroğlu, 2018) üniversite uyumuyla ilişkili olduğu gösterilmiştir. Herhangi bir zorlayıcı duruma veya yeni bir yaşam tarzına uyum sağlamada kişilik özelliklerinin önemli bir rol oynadığ dışadönüklük, uyumluluk, deneyime açıklık ve duygusal dengeli olmanın üniversite uyumunu kolaylaştırdığı birçok çalışmada gösterilmiştir (Credé ve Nieohorster, 2012). Özellikle sorumluluk kişilik özelliğine sahip olanların göstermiş olduğu düzenli ve gayretli olma çabaları akademik uyumun önemli bir yordayıcısıdır (Feldt ve ark., 2011).

Alan yazında kişilik özelliklerini ele alan pek çok yaklaşım olmakla birlikte araştırmalara konu olan en yaygın kişilik kuramı beş faktör kişilik modelidir (McCrae ve Costa, 2003). Bununla birlikte Eysenck'in (1967) üç faktörlü kişilik modeli ve daha güncel 
olan Gray'in (1982) pekiştirmeye duyarlık kuramı bireysel farklılıkların temelindeki biyolojik yatkınlıklara değinmektedir. Pekiştirmeye duyarlık kuramı beynin ödül ve ceza uyaranlarına duyarlılığına bağlı olarak yaklaşma ve kaçınma olmak üzere temelde iki güdü olduğunu ileri sürmektedir. Biyolojik yaklaşımların diğer yaklaşımlara göre bir avantajı kişiliğin işlevsel yönünü vurgulaması ve beş faktör modelindeki kişilik özelliklerinin yaklaşma ve kaçınma duyarlılığıyla yakından ilişkili olmasıdır (Carver ve Connor-Smith, 2010). Belirli kişilik özelliklerinin yanı sıra baş etme mekanizmaları da uyum süreciyle doğrudan ilişkili olabilmektedir. Lazarus ve Folkman (1984) bireylerin içsel ve dışsal zorluklar karşısında göstermiş oldukları bilişsel ve davranışsal çabaları baş etme olarak tanımlamışlardır. Problem çözme, sıkıntı verici durumları olumlu olarak yeniden değerlendirme, sosyal destek arama ve sıkıntılı durum, duygu ve düşünceleri kabullenme olumlu baş etme yöntemlerine; kaçınma, duygusal ve düşünsel bastırma, inkar ve madde kullanımı olumsuz baş etmeye örnek gösterilebilir. Mizah da araştırmacıların son yıllarda ilgisini çeken ve farklı türlerinin kavramsallaştırıldığı bir baş etme biçimidir (Martin, Puhlik-Doris, Larsen, Gray ve Weir, 2003). Gerek fiziksel gerek de ruhsal olarak zorlayıcı yaşam olayları karşısında mizahi bir yaklaşım sergileyen kişilerin bu durumlarla daha iyi baş ettikleri görülmektedir (Fritz, Russek ve Dillon, 2017).

Ülkemizde yapılan çalışmalarda da olumlu mizah kullanımının stresli durumlarda kişilerin kendilerini daha güvenli hissetmeleriyle (Özdemir, Sezgin, Kaya ve Recepoğlu, 2011), iletişim ve uyum sağlama becerileriyle (Özbay, Palancı, Kandemir ve Çakır, 2012), stresle başa çıkmayla (Dumanlı ve Köroğlu, 2018), psikolojik sağlıkla (Akdur ve Durak-Batıgün, 2018), öznel iyi oluş ve evlilik uyumuyla (Demirci, 2019) pozitif yönde ilişkili olduğu bulunmuştur. Mizahın üniversite uyumuyla ilişkisinin araştırıldığı çalışmalarda bir baş etme yöntemi olarak mizah kullanan öğrencilerin okulu birakma niyetlerinin daha düşük olduğu (Alkan, 2014), üniversite uyumunun bir alt alanı olan kişisel uyumlarının daha iyi olduğu (Rahat ve İlhan, 2016) bulunmuştur. Öte yandan Türkiye ve Amerika'daki öğrencilerle yapılan bir çalışmada mizah kullanımının genel uyum ile ilişkili olmadığı, üstelik akademik uyum ile negatif ilişkili olduğu bulunmuştur (Tuna, 2003). Ancak bu çalışmalarda mizahın sadece olumlu yönünün ele alınmış olmasından dolayı çalışmalar arasındaki çelişkili sonuçlar mizahı tek boyutlu olarak ele almaktan kaynaklanmış olabilir.

Kişilik-Baş Etme-Sonuç Kuramı (Personality-Coping-Outcome Theory; Gallagher, 1996) stresli bir durum karşısında kişilik özeliklerinin birtakım baş etme mekanizmala- 
rını ortaya çıkaracağını öne sürmektedir. Yani kişilik özellikleri insanların stresli bir durum sırasında kullandıkları baş etme yöntemleriyle ilişkili olabilmektedir (Carver ve Connor-Smith, 2010). Dolayısıyla uyumla pozitif ilişki gösteren kişilik özelliklerinin işlevsel baş etme mekanizmalarını sürece dahil ettiği düşünülmektedir. Bu sebepten kişilik özellikleri ve baş etme yöntemlerinin birlikte ele alınması hangi biyopsikososyal süreçlerin zorlayıcı koşullar altında olumlu çıktıları kolaylaştırdığının anlaşılmasında yardımcı olabilir. Bu noktadan hareketle bu çalışmada davranışsal aktivasyon ve inhibisyon kişilik özellikleri ile mizah tarzlarının üniversite uyumuyla doğrudan ilişkileri incelenecek; bunun yanı sıra kişilik özellikleri ve uyum ilişkisinde mizah tarzlarının aracı rolü de test edilecektir.

\section{Biyolojik Kişilik Yaklaşımının Temelleri: Yaklaşma ve Kaçınma Güdüleri}

Her birey günlük hayatta çeşitli duygu, düşünce ve davranışlara yol açan birçok durum ve ortamla karşılaşmaktadır. İş, okul veya hastane ortamında bulunmak, tehlikeli bir hayvanla karşılaşmak (örn., yılan, havlayan bir köpek), sevindirici bir haber almak, lezzetli bir yemek yemek, kritik bir iş görüşmesi yapmak ve sınava hazırlanmak gibi birçok durum hemen her insanda farklı düzeyde deneyimlenmektedir. Bazı uyaranlar kimisi için çekici olabilirken bazıları da itici olabilmektedir. Bu bireysel farklılıkların ise doğuştan gelen birtakım yapısal farklılıklardan kaynaklandığı öne sürülebilir. Gray (1982), biyolojik farklılıkların kişilik üzerindeki etkisini inceleyen araştırmacılardan (örn., Eysenck, 1967) yola çıkarak, insan davranışını güdüleyen iki farklı sistem olduğunu ileri sürmüştür. Gray (1982) tarafından geliştirilen Pekiştirmeye Duyarlılık Kuramı'na (Reinforcement Sensitivity Theory) göre, yaklaşma ve kaçınma güdüleri bu sistemin temel bileşenleri olarak kavramsallaştırılmaktadır. Yaklaşma güdüsü davranışsal aktivasyon sistemi (DAS) ve kaçınma güdüsü de davranışsal inhibisyon sistemi (DİS) olarak adlandırılır. Gray’e (1982) göre her iki sistem birbirinden bağımsız olarak çalışmaktadır ve farklı pekiştireçlere duyarlılık göstermektedir. Kişiliğin doğuştan gelen bu eğilimsel (dispositional) yönleri insanların çevresel uyaranları nasıl deneyimleyeceğini ve duygularını ne şekilde düzenleyeceğini büyük ölçüde belirlemektedir (Ford, McCreight ve Richardson, 2014).

DİS belirsizlik içeren yeni durumlara, ceza olasılığg olan ve ödüllendirici olmayan uyaranlara karşı insanların daha duyarlı olmalarını sağlar (Carver ve White, 1994). Böylece DİS duyarlılığı fazla olan kişilerin bu tarz uyaranlarla karşılaştıklarında daha fazla korku, anksiyete, engellenme ve üzüntü gibi duygular deneyimlemeye yatkın oldukları 
söylenebilir (Carver ve White, 1994; Heponiemi, Keltikangas-Järvinen, Puttonen ve Ravaja, 2003; Meyer, Olivier ve Roth, 2005; Voigt ve ark., 2009). Araştırmalar, DİS'in zarardan kaçınmayla ilişkili olduğunu (Mardaga ve Hansenne, 2007), bu sebeple bireylerin yeni uyaranlara veya ortamlara karşı daha tedbirli yaklaştıklarını göstermiştir (Viana ve Gratz, 2012). DİS duyarlılığı yüksek olan bireyler sosyal ilişkilerinde bozulma tehdidiyle veya sonucunda ceza alabilecekleri stresli durumlarla karşılaşmaları halinde daha fazla olumsuz duygulanım deneyimlemektedirler (Heponiemi ve ark., 2003; Meyer ve ark., 2005). Ayrıca bu bireylerin intihar düşüncelerine de daha meyilli oldukları rapor edilmiştir (Rasmussen, Elliot ve O'Connor, 2012). Geniş kapsamlı bir araştırmada DİS puanı yüksek olan bireylerin kaygı duyma eğilimlerinin fazla olduğu, DİS puanının kadınlarda erkeklere oranla daha yüksek olduğu, ancak her iki cinsiyetin de DİS puanlarının yaşla birlikte düştüğü bulunmuştur (Jorm ve ark., 1998). Çocukluk çağında deneyimlenen olumsuz yaşam olaylarının yetişkinlikte daha yüksek DİS puanını yordadığı (Rosenman ve Rodgers, 2006) ve DİS aşırı duyarlılığının klinik anksiyete ve depresyon gibi içselleştirme bozukluklarıyla ilişki olduğu gösterilmiştir (Bijttebier, Beck, Claes ve Vandereycken, 2009; Vervoort ve ark., 2010).

DAS ise organizmayı ödül uyaranlarına duyarlı kılmakla birlikte olumlu duyguların da daha fazla yaşanmasını sağlamaktadır (Carver ve White, 1994; Ford ve ark., 2014; Heponiemi ve ark., 2003). DAS hayattan keyif almayla ilişkili olmasına rağmen, bu sistemin duyarlılığı yüksek olan kişilerin yenilik ve ödül aramaya daha eğilimli oldukları söylenebilir (Mardaga ve Hansenne, 2007). Böylece aşırı DAS aktivasyonunun keyif verici uyaranlara daha fazla yönelmeyle, madde ve alkol kötüye kullanımı gibi riskli davranışlarla (Franken ve Muris, 2006; Voigt ve ark., 2009) ve dışsallaştırma bozuklukları olarak bilinen dikkat eksikliği ve hiperaktivite bozukluğu, davranım bozukluğu ve antisosyal kişilik bozukluğuyla ilişkili olabileceği bulunmuştur (Bijttebie ve ark., 2009; Hundt, Kimbrel, Mitchell ve Nelson-Gray, 2008). Sonuç olarak, davranışı güdüleyen sistemlerdeki bu temel bireysel farklılıkların herhangi bir durumun, özellikle yeni bir uyaranın, tehdit edici veya ödüllendirici olarak algılanıp algılanmamasında belirleyici rol oynadığı düşünülmektedir.

\section{Kişilik Özellikleri ve Üniversiteye Uyum}

Üniversite yaşamının ilk yılları gençlerin hem içinde bulundukları gelişimsel dönemden hem de bu dönemin geçmiş yaşantılarından birçok açıdan farklılık gösterebilecek özelliklerinden dolayı bazı gençler için oldukça zorlayıcı olabilmektedir. Üniversite 
yaşamına uyum başı başına önemli sonuçları olan bir durumdur. Alan yazında birçok faktörün uyum süreciyle ilişkili olabileceği bulunmuştur.

Baker ve Siryk (1984) üniversiteye uyumu akademik, sosyal, kişisel-duygusal ve kurumsal uyum gibi farklı boyutlarla ele almıştır. Bu alanlarda gençlerin yaşadıkları zorluklar üniversiteye uyum süreciyle başarılı biçimde baş etmelerini güçleştirebilmektedir. Bu durum ise öğrencilerin derse devam edememeleri, okulu bırakmaları, kendilerine yönelik olumsuz duygular geliştirmeleri, alkol ve madde kullanımlarının artması ve psikolojik iyi oluşlarının bozulmasına neden olabilmektedir (Dyson ve Renk, 2006; Pritchard, Wilson ve Yamnitz, 2007; Vella-Zarb ve Elgar, 2010). Ülkemizde üniversite uyumu üzerinde yapılan çalışmalarda sosyo-demografik faktörlerin yanı sıra (Aladăg Bayrak ve Bülbül, 2013) içsel ve sosyal psikolojik faktörlerin de uyumla ilişkili olduğu gösterilmiştir. İletişim becerileri yüksek olan (Ceyhan, 2006) ve sosyal çevrelerini destekleyici olarak şekillendirebilen gençlerin (Duru, 2016) daha iyi uyum sağladıkları bulunmuştur. Yakın zamanlı çalışmalarda da bireylerin daha çok erken yaşantılarıyla kişiliklerini şekillendiren ve göreceli olarak süreğen psikolojik durumların da (örn., ayrılık anksiyetesi ve erken dönem uyumsuz şemalar) üniversiteye uyumlarıyla negatif yönde ilişkili olduğu bulunmuştur (Akhunlar Turgut ve ark., 2018; Y1ldız, 2018). Önemli bir koruyucu faktör olan psikolojik dayanıklılık da üniversite uyumuyla çok yüksek düzeyde ilişkili bulunmuştur (Kaba ve Keklik, 2016).

Uyum sürecinde kişinin algıladığı stres düzeyinin ve yaşadığı zorlukların sahip olduğu kişilik özellikleriyle ilişkili olduğu söylenebilir. Örneğin ceza duyarlılığının yüksek olduğu nevrotiklik kişilik özelliği ve ödül duyarlılığının oldukça az olduğu aşırı içe dönük olma üniversite öğrencilerinde uyumu olumsuz etkilerken, psikolojik stresin daha yoğun deneyimlenmesine neden olabilmektedir (Warbah ve ark., 2007). Bir çalışmada dışadönüklerin (ödül duyarlılığı yüksek kişiler) üniversite hayatının stresini daha az deneyimledikleri, nevrotiklik puanı yüksek olan kişilerin ise daha fazla stres yaşadıkları gösterilmiştir (Lu, 1994). Beş Faktör Kişilik özellikleri açısından bakıldığında üniversite uyumuyla dışadönüklük, sorumluluk, uyumluluk ve deneyime açıklık pozitif yönden ilişkiliyken; nevrotikliğin ise uyum sürecini zorlaştıran bir özellik olduğu ortaya çıkmaktadır (Credé ve Nieohorster, 2012). Alan yazında üniversite uyumu ile kişilik özelliklerinin ilişkisinin incelendiği araştırmalarda kişiliğin Beş Faktör Kişilik özellikleri açısından ele alınmış olduğu saptanmış, ancak biyolojik yaklaşımla incelendiği bir çalışma olmadığ1 görülmüştür. Bu sebepten bu çalışmada kişilik özelliklerinin Pekiştirme- 
ye Duyarlılık Kuramı (Corr, 2004) doğrultusunda davranışsal aktivasyon ve davranışsal inhibisyon kişilik özellikleri bağlamında incelenmesi hedeflenmiştir. Davranışsal aktivasyon düzeyi yüksek kişilerin yeniliğe açık, strese daha az duyarlı ve hedef odaklı oldukları; buna karşıllı davranışsal inhibisyon düzeyi yüksek olanların ise belirsizlik içeren yeni durumlara ve engellenmeye duyarlı oldukları göz önüne alınarak aşağıdaki hipotez kurulmuştur.

$H_{1}$ : Davranışsal aktivasyon üniversite uyumunu pozitif yönde, davranışsal inhibisyon ise üniversite uyumunu negatif yönde yordayacaktır.

\section{Bir Baş Etme Yöntemi Olarak Mizah}

Freud (1905) mizahı hoş olmayan durumlardan kurtulmak için kullandığımız olgun bir savunma mekanizması olarak tanımlar (Akt., Özdolap, 2015). Birey korku, üzüntü, öfke benzeri olumsuz duygular yaşadığında, eğlence algısı veya bazı durumlardaki çelişkili öğeler bakış açısını değiştirmesini sağlar ve bu duygulardan uzaklaşmaya olanak tanır. Böylece kişi, duygulara yönelik bir enerji tasarrufu elde etmiş olur, bu da hazzı meydana getirir. (Freud, 1905; akt., Özdolap, 2015).

Ampirik çalışmalar stresli durumlar karşısında mizaha başvurmayı etkili bir baş etme yöntemi olarak tespit etmiştir (Overholser ve Adams, 1997). Mizah, içinde bulunulan durumu bilişsel ve duygulanımsal (afektif) olarak yeniden yapılandırma süreci olarak tanımlanabilir (Martin, Kuiper, Olinger ve Dance, 1993). Buna göre sorunlarla karşılaşıldığında mizahi bir yaklaşım sergileyen kişi, durumla arasına mesafe koyarak sorunu daha az tehdit edici ve stresli olarak algılamaktadır (Martin ve ark., 1993). Yani kişi olumsuz olay veya durumları daha az sıkıntı duyacağı bir şekilde yeniden değerlendirir ve kendisine olumlu katkıları olabilecek yaşantılar olarak görmeye çalışır. Bunu yaparken de mizahi bir yaklaşım sergiler.

Araştırmalar mizahi yönleri gelişmiş kişilerin daha az duygudurum bozuklukları gösterdiklerini (Martin ve Lefcourt, 1983), bağışıklık sistemlerinin viral ve bakteriyel enfeksiyonlara karşı daha dayanıklı olduğunu (Martin ve Dobbin, 1998; akt., Vilaythong, Arnau, Hosem ve Mascaro, 2003), mizahın yalnızlık ve depresyona karşı koruyucu olduğunu ve yüksek öz-saygı ile ilişkili olduğunu göstermektedir (Overholser, 1992). Bununla birlikte mizah ile ilgili yapılan ilk çalışmaların stres üzerindeki olumlu etkisine ilişkin tutarsız bulgular (örn., Korotkov ve Hannah, 1994; Martin ve Lefcourt, 1983; Porterfield, 1987; Safranek ve Schill, 1982; Vilaythong ve ark., 2003), mizah duygusu- 
nun çok boyutlu olarak (yani olumsuz mizah tarzlarını da dahil ederek) ele alınmasının gerekliliğini ortaya çıkarmıştır (Martin, 2001).

Martin ve arkadaşları (2003) dört farklı mizah tarzı belirlemişlerdir. Bunlardan ikisi kişinin kendisine ve diğerlerine karşı olumlu, diğer ikisi de olumsuz veya zararlı nitelikteki mizah anlayışlarıdır. Kendini geliştirici mizah, kişilerin yaşama karşı mizahi bir tutum sergilemesini ve zor koşullar altında olaylara mizahi bir bakış açısıyla yaklaşımını ifade eder. Katılımcı mizah, kişinin sosyal ilişkilerini geliştirmek için diğerlerini eğlendirdiği ve güldürdüğü mizah tarzıdır. Bir çalışmada kendini geliştirici ve katılımcı mizah sağlıklı sosyal ilişkiler ve psikolojik iyi oluşla ilişkili bulunmuştur (Kuiper, 2010). Saldırgan mizah, diğerleri üzerinde üstünlük kurmak için kişinin diğerlerini aşağılayıcı bir şekilde mizaha başvurmasını ifade eder (Martin ve ark., 2003). Bu mizah tarzı kişiler arası ilişkileri olumsuz etkilemektedir (Cann, Zapata ve Davis, 2011). Son olarak kendini yıkıcı mizah, kişilerin diğerlerini eğlendirmek için kendini aşağılamasını ifade eder (Martin ve ark., 2003). Bu kişiler mizahı sorunlardan ve olumsuz duygularla baş etmekten kaçınmak için kullanırlar (Ford ve ark., 2014). Ülkemizde yapılan bir çalışmada kendini geliştirici ve katılımcı mizah psikolojik sorunlarla negatif yönde, saldırgan ve kendini yıkıcı mizah ise pozitif yönde ilişkili bulunmuştur (Akdur ve Durak-Batıgün, 2018). Bir diğer çalışmada olumlu mizah tarzları öznel iyi oluşla pozitif yönde, olumsuz mizah tarzları ise negatif yönde ilişki oluşturmuştur (Reisoğlu ve Yazıcı, 2017). Genel olarak olumlu mizah kullanımı hem psikolojik hem de fiziksel olarak sıkıntıların daha hafif düzeyde deneyimlenmesini ve stresli koşullara daha etkili bir şekilde uyum göstermeyi sağlamaktadır (Fritz ve ark., 2017). Bu sebeple farklı mizah tarzlarının üniversite uyumunu farklı yönlerde etkileyebileceği düşünülerek aşağıdaki hipotez kurulmuştur.

$H_{2}$ : Kendini geliştirici ve katılımcı mizah üniversite uyumunu pozitif yönde, kendini yıkıcı ve saldırgan mizah üniversite uyumunu negatif yönde yordayacaktır.

Bununla birlikte kişilik özellikleri ile uyum süreci arasında birtakım baş etme mekanizmaları rol oynamaktadır. Yani bireysel özelliklerin herhangi bir durumun sonucuyla doğrudan değil dolaylı olarak ilişkili olduğu düşünülebilir. Lu'nun (1997) çalışmasında elde edilen bulgular dişa dönük yani ödüle duyarlı, enerjik ve olumlu duyguları daha fazla deneyimleyen kişilerin üniversite uyumlarının daha iyi olduğunu göstermektedir. Bu kişilerin sahip olduğu yaklaşma güdüleri sorun yaşadıkları zaman daha çözüm odaklı, sosyal destek arayışı içinde ve bilişsel olarak daha olumlu bir tu- 
tum içinde olmalarına yardımcı olabilir. Benzer şekilde ceza duyarlılığı yüksek olan nevrotik kişiler ise daha kaçınma eğilimli bir baş etme içinde olabilmektedirler (Carver ve Connor-Smith, 2010).

Çalışmalar DAS eğilimi yüksek ve dışa dönük kişilerin daha fazla olumlu mizah tarzı kullanarak olumlu duygular yaşadıklarını göstermektedir (Ford ve ark., 2014; Ford, Lappi ve Holden, 2016). Üniversite öğrencilerinin uyum sürecinde algılanan stres düzeylerinin narsisizm kişilik özellikleriyle ilişkisinin incelendiği bir çalışmada kırılgan narsisizmin algılanan stresi yordadığı ve bu ilişkide kendini yıkıcı ve saldırgan mizahın aracı rolü olduğu bulunmuştur (Besser ve Zeigler-Hill, 2011). Dolayısıyla mizah tarzlarının kişilik özellikleriyle ilişkili olan bir baş etme yöntemi olduğuna ilişkin bulgular alan yazında belirmeye başlamıştır. Bu doğrultuda davranışsal aktivasyon-inhibisyon kişilik özellikleri ve üniversite uyumu arasındaki ilişkide mizah tarzlarının aracı rolünün incelenmesi de amaçlanmıştır.

Alan yazında dışadönük, ödüle duyarlı ve sosyal bireylerin daha fazla katılımcı ve kendini geliştirici mizah kullandıkları, buna karşı1ık nevrotik bireylerin ise daha fazla kendini yıkıcı ve saldırgan mizah kullandıkları bulunmuştur (Martin ve ark., 2003; Plessen ve ark., 2020). DİS ve nevrotizmin yüksek düzeyde ilişkili ve DİS'in nevrotizmin biyolojik temeli olduğu kabul edilse de (Barlow, Sauer-Zavala, Carl, Bullis ve Ellard, 2014), bu çalışmada saldırgan mizah tarzının DİS ve üniversite uyumu arasında aracılık rolü beklenmemektedir. Çünkü nevrotizmin diğer özellikleri de duygusal oynaklık ve öfke kontrol sorunlarıdır (McCrae ve Costa, 2003). Dolayısıyla saldırgan mizahla pozitif ilişkisi bu yolla açıklanabilir. Ancak DİS daha çok cezaya duyarlı olmakla ilişkilidir ve endişe, anksiyete, üzüntü, engellemeler karşısında çabuk hayal kırıklığına uğrama gibi göreceli olarak olumsuz, pasif psikolojik deneyimlerle ilişkilidir. Buradan yola çıkarak uyumu kolaylaştıran kişilik özelliğinde (DAS) olumlu mizah tarzlarının, uyumla negatif ilişkili olan kişilik özelliğinde (DİS) ise olumsuz mizah tarzının kullanılması beklenmektedir.

$H_{3}$ : Davranışsal aktivasyon ve üniversite uyumu arasında a) kendini geliştirici mizahın ve b) katılımcı mizahın aracı rolü vardır.

$H_{4}$ : Davranışsal inhibisyon ve üniversite uyumu arasında kendini yıkıcı mizahın arac1 rolü vardır. 


\section{YÖNTEM}

\section{Katılımcılar}

Çalışmaya Türkiye'de bir devlet üniversitesinde eğitim gören ve üniversiteye yeni kayıt olan 282 öğrenci katılmıştır. Katılımcılar 2017-2018 eğitim öğretim yılı bahar döneminde fen edebiyat fakültesinin psikoloji, sosyoloji ve felsefe bölümlerinin psikolojiye giriş dersini alan öğrencilerdir. Üniversitenin ilk ayları herkes için sıkıntılı olabileceği ve uyumu değerlendirmek adına uygun bir vakit olamayacağı sebebiyle çalışmanın verileri eğitim yılı başladıktan 6 ay sonra 2018 yılının Mart ayında toplanmıştır. Kolayca ulaşılabilir örnekleme yöntemiyle seçilen katılımcıların \%68.5'i kadın $(N=193)$, \%30.9'u erkektir $(N=87)$. Katılımcıların yaş aralığı 17-29, yaş ortalaması $19.56(S S=$ 1.36) olarak hesaplanmıştır.

\section{Veri Toplama Araçları}

Davranışsal Aktivasyon-İnhibisyon Ölçeği. Davranış ve duygulanımın altında yatan yaklaşma ve kaçınma güdülerini değerlendirmek amacıyla Carver ve White (1994) tarafından geliştirilmiştir. Öz bildirim ölçeği olarak geliştirilen form 24 maddeden oluşmaktadır. Dört madde dolgu maddesi olup ölçek 20 madde üzerinden değerlendirilmektedir. Katılımcılar her bir maddede dörtlü Likert tipi (1 = Hiç katılmıyorum, 4 = Tamamen katılıyorum) ölçek ile kendilerini değerlendirirler. Ölçek davranışsal inhibisyon faktörü ve davranışsal aktivasyonun alt boyutları olan eğlence arayışı, ödüle duyarlılık ve dürtü olmak üzere toplam dört faktörden oluşmaktadır. Alınan puanların yükselmesi ilgili boyuttaki duyarlılığın yüksekliğine işaret eder. Orijinal çalışmada DİS faktörü için iç tutarlılık katsayısı .74 olarak hesaplanmıştır. DAS'ın faktörleri için ise eğlence arayışı .66, ödüle duyarlılık .73 ve dürtü .76 olarak bulunmuştur.

Ölçeğin Türkçe uyarlaması Şişman (2012) tarafından yapılmıştır. Faktör analizi sonuçları orijinal formdaki dört faktörü karşılamıştır. Uyarlama çalışmasında iç tutarlılık kat sayısı DİS için .69, DAS faktörleri için ise eğlence arayışı .63, ödüle duyarlılık .57 ve dürtü .69 olarak bulunmuştur. Birleşen geçerlik tespiti için yapılan korelasyon analizi sonucunda Heyecan Arama Ölçeği (Beyaz, 2004) ve I-7 Dürtüsellik Ölçeği (akt. Şişman, 2012) puanları ile DİS arasında negatif yönde, DAS ile pozitif yönde ilişki bulunmuştur.

Gray (1990) DAS'1 yaklaşma güdüsünün temelini oluşturan nörobiyolojik bir yap1 olarak tanımlamıştır. Carver ve White'ın (1994) çalışmasında ölçek üç faktörden oluş- 
muştur. Ancak bu araştırmacılar da alt boyutların faktör yüklerinin ikinci düzey faktöre yüklendiklerini dolayısıyla üç faktörün birbiriyle yakından ilişkili olduğunu ifade etmişlerdir. Yakın zamanlı bir çalışmada da (Ford ve ark., 2014) faktörler hem birbirleriyle hem de toplam puanla yüksek düzeyde ilişkili bulunmuştur. Bu araştırmada faktörlerin her birinin bağımsız ilişkisinden çok genel olarak ödül duyarlılı̆̆ının üniversite uyumuyla ilişkisinin incelenmesi amaçlandığı için toplam puan hesaplanmıştır.

Mizah Tarzları Ölçeği. Mizah Tarzları Ölçeği mizah kullanımındaki bireysel farklılıklara ilişkin dört farklı boyutu ölçmek amacıyla Martin ve arkadaşları (2003) tarafından geliştirilmiştir. Otuz iki maddeden oluşan ölçek öz bildirim formu olup yedili Likert ( 1 = Kesinlikle katılmıyorum, 7 = Tamamıla katılıyorum $)$ tipindedir. Ölçeğin dört faktörü sırasıyla kendini geliştirici mizah (KGM), katılımcı mizah (KM), kendini yıkıcı mizah (KYM) ve saldırgan mizah (SM) olarak adlandırılmıştır. Ölçeğin orijinal formu için 179 öğrenci ile yapılan test-tekrar test ölçümleri sonucu iç tutarlılık katsayıları tüm faktörler için .80 ile .85 arasındadır.

Ölçeğin Türkçe uyarlaması Yerlikaya (2003) tarafindan 1363 üniversite öğrencisi ile yapılmıştır. Ölçeğin toplam iç tutarlılık katsayısı .81, test-tekrar test korelasyon katsay1s1 .91 olarak hesaplanmıştır. Faktörlerin Cronbach alfa iç tutarlılık katsayıları kendini geliştirici mizahta 0.78 , katılımcı mizahta 0.74 , saldırgan mizahta 0.69 ve kendini yıkıcı mizahta ise 0.67 olarak hesaplanmıştır. Test-tekrar test güvenirlik katsayıları ise iyi düzeyde bulunmuştur (sırasıyla; kendini geliştirici mizah $=.83$, katılımcı mizah $=.88$, saldırgan mizah $=.85$, kendini yıkıcı mizah $=.85$ ). Ölçeğin yapı geçerliği için uygulanan faktör analizi sonucunda orijinal çalışmaya uygun olarak dört faktörden oluştuğu saptanmıştır. Ölçüt bağıntılı geçerlik için Durumluk Mizah Tepkisi Ölçeği’nin (Aydın, 1993) tüm faktörlerle pozitif yönde; depresyon ve benlik saygısı puanları olumlu mizah tarzlarıyla negatif yönde, kendini yıkıcı mizah tarzıyla pozitif yönde ilişkili bulunmuştur. Ölçekten alınan puanların artması ilgili faktördeki mizah tarzının yüksekliğini göstermektedir.

Üniversite Yaşamı Ölçeği. Üniversiteye yeni başlayan öğrencilerin uyum düzeylerini ölçmek amacıyla geliştirilen ölçek 48 maddelik öz bildirim formudur (Aladağ, Kağnıc1, Tuna ve Tezer, 2003). Üniversite ortamına uyum, duygusal uyum, kişisel uyum, karşı cinsle ilişkiler, akademik uyum ve sosyal uyum olmak üzere altı faktörü vardır. Ölçek yedili Likert tipindedir (1 = Bana hiç uygun değil, 7 = Bana tamamen uygun). 
Ölçekten alınan düşük puanlar uyumsuzluğa, yüksek puanlar ise uyumluluğa işaret etmektedir. Faktörlere ilişkin iç tutarlılık katsayıları .60 ile .80 arasında değişmektedir, ölçek toplam puanı için iç tutarlılık katsayısı .91 olarak hesaplanmıştır. Ölçeğin yapı geçerliği için faktör analizi uygulanmış olup altı faktörlü bir yapıya ulaşılmıştır. Ölçeğin toplam puanının son derece güvenilir olmasından $(a=.90)$ ve faktörlerin hepsinin toplam puanla $r>.67$ düzeyinde yüksek bir ilişki göstermesinden dolayı bu çalışmada toplam puan kullanılmıştır.

\section{İşlem}

Araştırma verileri üniversiteye yeni kayıt olan lisans öğrencilerinden psikolojiye giriş dersini alanlardan ders saatinde anket yoluyla toplanmıştır. Uygulama öncesi katılımcılara çalışmanın amacı açıklanmış, çalışmaya katılımda gönüllülüğün esas olduğu bildirilmiştir. Katılımdan dolayı herhangi bir ücret veya ders kredisi verilmemiştir. Uygulama yaklaşık 20 dakika sürmüştür.

\section{Veri Analizi}

Elde edilen veriler, SPSS 20 paket programı ile çözümlenmiştir. Aracılık analizleri için Hayes'in (2016) geliştirdiği SPSS eklentili "PROCESS 2.16.1” programı kullanılmıştır.

İlk olarak öğrencilerin ölçeklerden aldıkları puanlara dair tanımlayıcı istatistikler (ölçeklerden alınan minimum, maksimum, ortalama ve ortalamaya ait standart sapma değerleriyle ölçeklerin Cronbach alfa güvenirlik katsayıları) hesaplanmıştır. Değişkenler arasındaki ilişki Pearson momentler çarpımı bağıntı katsayılarıyla incelenmiştir. DAS ve DİS ile mizah tarzlarının üniversite yaşamına uyumu ne yönde yordadıklarını tespit etmek amacıyla çoklu doğrusal regresyon analizi yapılmıştır. Kişilik özellikleri ile üniversiteye uyum arasındaki ilişkide mizah tarzlarının aracılık etkileri Hayes'in (2016) geliştirdiği dördüncü model ile incelenmiştir. Aracılık ilişkisinin anlamlılığını test ederken 5000 yeniden örnekleme (bootstrapping) tekniği kullanılarak \%95 güven aralıkları hesaplanmıştır.

\section{BULGULAR}

\section{Değişkenlerin Tanımlayıcı İstatistikleri, Güvenirlik Katsayıları ve Korelasyonları}

Araştırmada ilk olarak değişkenlerin tanımlayıcı istatistikleri ve Cronbach alfa iç tutarlılık katsayıları hesaplanmıştır. Kullanılan değişkenlerin tanımlayıcı istatistikleri, iç tutarlık katsayıları ve birbirleriyle korelasyonları Tablo 1'de gösterilmektedir. 
Tablo 1. Değişkenlere Ait Tanımlayıcı İstatistikler, Güvenirlik Katsayıları ve Korelasyonlar

\begin{tabular}{|c|c|c|c|c|c|c|c|c|c|}
\hline & Ort. & $S S$ & 1 & 2 & 3 & 4 & 5 & 6 & 7 \\
\hline 1. Üniversite Uyumu & 228.10 & 35.79 & $(.90)$ & $-.15^{* *}$ & $.18^{* *}$ & $.18^{* *}$ & $.31^{* *}$ & $-.19^{* * *}$ & .00 \\
\hline 2. Davranışsal İnhibisyon Sistemi & 20.16 & 4 & & $(.76)$ & $.16^{* *}$ & -.06 & $.12 *$ & .03 & $-.20^{* *}$ \\
\hline 3. Davranışsal Aktivasyon Sistemi & 42.62 & 4.95 & & & $(.72)$ & $.23^{* *}$ & $.20^{* *}$ & .10 & .00 \\
\hline 4. Kendini Geliştirici Mizah & 37.83 & 8.56 & & & & $(.73)$ & $.30^{* *}$ & $.41^{* *}$ & .10 \\
\hline 5. Katılımeı Mizah & 40.14 & 7.40 & & & & & $(.66)$ & $.13^{*}$ & $.12^{*}$ \\
\hline 6. Kendini Yıkıcı Mizah & 28.88 & 9.20 & & & & & & $(.74)$ & $.20^{* *}$ \\
\hline 7. Saldırgan Mizah & 26 & 6.35 & & & & & & & (.44) \\
\hline
\end{tabular}

Not. ${ }^{*} p<.05 ; * *<.01$. Cronbach $\alpha$ güvenirlik katsayıları diyagonalde parantez içinde sunulmuştur.

Ölçeklerin iç tutarlıkları incelendiğinde mizah tarzlarından saldırgan mizahın güvenirlik katsayısı çok düşük çıktığı için $(a=.44)$ hipotez testi analizlerine bu değişken dahil edilmemiştir. Katılımcı mizahın iç tutarlık katsayısı .66 ile diğer ölçeklere göre daha düşük bir güvenirlik katsayısı sunsa da kabul edilebilir düzeyde olduğu düşünülmüştür. Kişilik özellikleri ve üniversite uyumu ölçümlerinin iç tutarlık katsayıları güvenilir bir ölçüm sunmaktadır.

Değişkenler arası korelasyonlar incelendiğinde üniversiteye uyumun DİS ile negatif yönde $(r(280)=-.15)$, DAS ile pozitif yönde $(r(280)=.18)$ ilişkili olduğu tespit edilmiştir. Mizah tarzlarından kendini geliştirici mizah ve katılımcı mizah üniversite yaşamına uyumla pozitif yönde (sırasıyla $r(280)=.18$ ve $r(280)=.31)$, kendini yıkıcı mizah ise negatif yönde $(r(280)=-.19)$ ilişkilidir.

\section{Üniversite Uyumunu Yordayan Değişkenlere İlişkin Regresyon Analizi}

DİS, DAS, kendini geliştirici mizah, katılımcı mizah ve kendini yıkıcı mizahın üniversiteye uyum üzerindeki yordayıcı etkisini incelemek amacıyla çoklu doğrusal regresyon analizi yapılmıştır. Modelin üniversite uyumundaki toplam varyansın \%24'ünü açıkladığg1 görülmüştür, $F(5,276)=17.82, p<.001$. Modeldeki değişkenlerin her birinin üniversite yaşamına uyumu anlamlı olarak açıkladığı tespit edilmiştir (Bkz. Tablo 2).

Tablo 2. Üniversite Uyumunu Yordayan Değişkenler

\begin{tabular}{lccccc}
\hline & \multirow{2}{*}{$\boldsymbol{B}$} & $\boldsymbol{t}$ & $\boldsymbol{p}$ & \multicolumn{2}{c}{$\boldsymbol{B}$ için \%95 GA } \\
\cline { 5 - 6 } & & & & Alt sınır & Üst sınır \\
\hline Davranışsal İnhibisyon Sistemi & -1.72 & -3.57 & $<.001$ & -2.666 & -.770 \\
Davranışsal Aktivasyon Sistemi & .97 & 2.45 & .015 & .191 & 1.758 \\
Kendini Geliştirici Mizah & .77 & 3.02 & .003 & .270 & 1.277 \\
Katılımcı Mizah & 1.43 & 5.31 & $<.001$ & .904 & 1.966 \\
Kendini Yıkıcı Mizah & -1.25 & -5.60 & $<.001$ & -1.695 & -.813 \\
\hline
\end{tabular}


Tablo 2 incelendiğinde, $H_{1}$ ve $H_{2}$ 'nin desteklendiği görülmüştür. Buna göre DİS ( $B=$ $-0.72, S H=0.48)$ ve kendini y1k1c1 mizah $(B=-1.25, S H=0.22)$ üniversite uyumunu negatif yönde; DAS $(B=0.97, S H=0.40)$, katılımc1 mizah $(B=1.43, S H=0.27)$ ve kendini geliştirici mizah $(B=0.77, S H=0.26)$ üniversite uyumunu pozitif yönde yordamaktadır.

\section{Aracılık Analizleri}

DAS ve üniversiteye uyum ilişkisinde kendini geliştirici ve katılımcı mizah tarzlarının aracı rolleri incelenmiştir. Ayrıca DİS ve üniversiteye uyum ilişkisinde kendini yıkıcı mizah tarzının aracı rolü test edilmiştir (Bkz. Tablo 3).

Tablo 3. Biyolojik Kişilik Özellikleri ve Üniversite Uyumu Arasındaki İlişkide Mizah Tarzlarının Aracılık Rolüne İlişkin Analiz Sonuçları

\begin{tabular}{lccccc}
\hline Yordayıcı değişken & $\begin{array}{c}\text { Toplam Etki } \\
\text { (c yolu) }\end{array}$ & $\begin{array}{c}\text { Doğrudan Etki } \\
\text { (c' yolu) }\end{array}$ & $\begin{array}{c}\text { Dolaylı Etki } \\
\text { (ab yolu) }\end{array}$ & Güven Aralığı & $\begin{array}{c}\text { Sobel } z \\
\text { testi }\end{array}$ \\
\hline Davranışsal Aktivasyon Sistemi & $1.27^{* *}$ & $1.01^{*}$ & $\mathrm{KGM}=0.25$ & {$[0.08-0.51]$} & $2.09 *$ \\
Davranışsal Aktivasyon Sistemi & $1.27^{* *}$ & $0.84^{*}$ & $\mathrm{KM}=0.41$ & {$[0.17-0.78]$} & $2.79 *$ \\
Davranı̧sal İnhibisyon Sistemi & $-1.38^{* *}$ & $-1.33^{* *}$ & $\mathrm{KYM}=-0.04$ & {$[-0.29-0.19]$} & -0.39 \\
\hline
\end{tabular}

Not. ${ }^{*} p<.05 ;{ }^{*} p<.01$. Tablodaki değerler 5000 yeniden örnekleme (bootstrapping) yaklaşımıyla hesaplanan standardize olmayan regresyon katsayıları ve çarpıklığı düzeltilmiş \%95 güven aralıklarıdır (bias-corrected $95 \%$ confidence intervals). Sonuç değişkeni = Üniversiteye uyum. $\mathrm{KGM}=$ Kendini geliştirici mizah; KM = Katılımcı mizah

Tablo 3'te gösterilen sonuçlara göre DAS'ın üniversiteye uyum üzerindeki toplam etkisi $(B=1.27, S H=0.43, p<.001)$ kendini geliştirici $(B=0.63, S H=0.25)$ ve kat1lımcı mizah tarzının $(B=1.40, S H=0.27)$ modele dahil olmasıyla azalma göstermektedir (doğrudan etki). DAS ve üniversiteye uyum arasındaki ilişkide hem kendini geliştirici mizah $(\% 95 \mathrm{GA}=[0.08,0.51])$ hem de katılımc1 mizah tarz1 $(\% 95 \mathrm{GA}=[0.17,0.78])$ aracılık etmektedir. 5000 yeniden örnekleme (bootstrapping) yöntemiyle hesaplanan güven aralıklarının sıfırı kesmemesi aracı değişkenin anlamlılığını göstermektedir. Ayrıca Sobel (1982) testi de aracılık ilişkisinin anlamlılığını göstermektedir (kendini geliştirici mizah tarzı için $z=2.09, p<.05$ ve katılımcı mizah tarzı için $z=2.79, p<.05$ ). Buna göre $H_{3}$ desteklenmiştir. Şekil 1 ve 2'de aracılık modeline ilişkin yollar gösterilmiştir. 


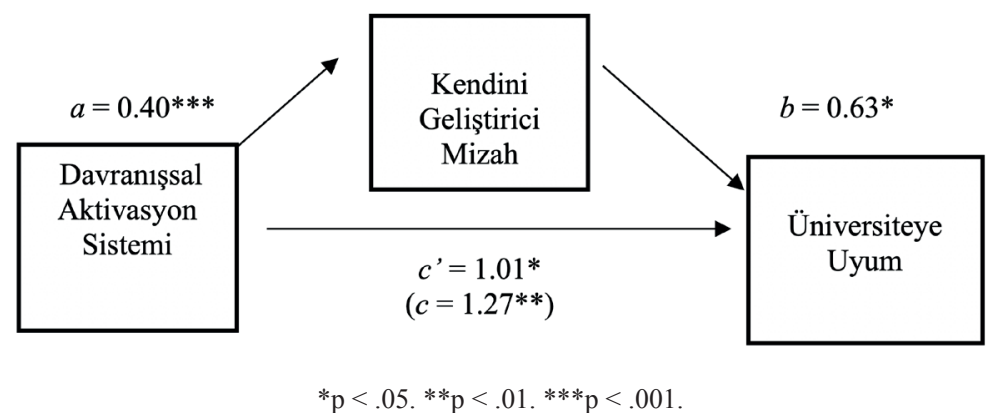

Şekil 1. Davranışsal Aktivasyon Sistemi ile Üniversiteye Uyum Arasındaki İlişkide Kendini Geliştirici Mizahın Aracılık Etkisini Gösteren Model.

Şekil 1 incelendiğinde davranışsal aktivasyon sisteminin üniversiteye uyumla ilişkisinde kendini geliştirici mizah tarzının kısmi aracılık rolü olduğu görülmektedir. Davranışsal aktivasyon sisteminin başlangıçtaki toplam etkisi ( $c$ yolu, $B=1.27, S H=0.43$ ) anlamlı bulunmuştur. Ayrıca aracılık modelindeki davranışsal aktivasyon sistemi ile kendini geliştirici mizah tarzı ( $a$ yolu, $B=0.40, S H=0.10$ ) ve kendini geliştirici mizah tarzı ile üniversite uyumu ( $b$ yolu, $B=0.63, S H=0.25$ ) arasındaki regresyon katsayıları istatistiksel olarak anlamlı bulunmuştur. Bu iki yolun regresyon katsayılarının çarpımından elde edilen dolaylı etki ( $a b$ yolu, $B=0.25, S H=0.11$ ), toplam etkinin ( $c$ yolu) regresyon katsayısında anlamlı bir düşüş göstermiştir. Toplam yolun etkisinden dolaylı yolun etkisi çıkarıldığında ortaya çıkan doğrudan yolun ( $c^{\prime}$ yolu, $B=1.01, S H=0.43$ ) sonuç değişkeni üzerindeki istatistiksel olarak anlamlı etkisi hala devam ettiği için dolaylı yolun kısmi aracı rolünde olduğu bulunmuştur.

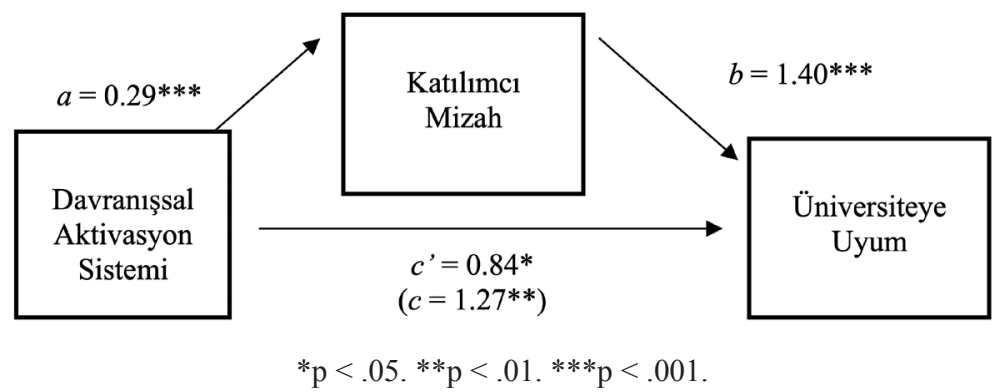

Şekil 2. Davranışsal Aktivasyon Sistemi ile Üniversiteye Uyum Arasındaki İlişkide Katılımıı Mizahın Aracılık Etkisini Gösteren Model.

Şekil 2 incelendiğinde davranışsal aktivasyon sisteminin üniversiteye uyumla ilişkisinde katılımcı mizah tarzının kısmi aracılık rolü olduğu görülmektedir. Davranışsal ak- 
tivasyon sisteminin başlangıçtaki toplam etkisi ( $c$ yolu, $B=1.27, S H=0.43$ ) anlamlı bulunmuştur. Ayrıca aracılık modelindeki davranışsal aktivasyon sistemi ile katılımcı mizah tarzı ( $a$ yolu, $B=0.30, S H=0.09$ ) ve katılımcı mizah tarzı ile üniversite uyumu ( $b$ yolu, $B=0.84$, $S H=0.42$ ) arasındaki regresyon katsayıları istatistiksel olarak anlam11 bulunmuştur. $\mathrm{Bu}$ iki yolun regresyon katsayılarının çarpımından elde edilen dolaylı etki ( $a b$ yolu, $B=0.42$, $S H=0.15$ ), toplam etkinin (c yolu) regresyon katsayısında anlamlı bir düşüş göstermiştir. Toplam yolun etkisinden dolaylı yolun etkisi çıkarıldığında ortaya çıkan doğrudan yolun ( $c$ ' yolu, $B=0.85, S H=0.42$ ) sonuç değişkeni üzerindeki istatistiksel olarak anlamlı etkisi hala devam ettiği için dolaylı yolun kısmi aracı rolünde olduğu bulunmuştur.

DİS ile üniversiteye uyum arasındaki ilişkide kendini yıkıcı mizah tarzının aracı rolü test edilmiştir. İstatistiksel analiz sonucunda kendini yıkıcı mizahın aracı rolü (ab yolu, $B=-0.04, S H=0.12, \% 95 \mathrm{GA}=[-0.29,0.19]$ ) olmadı ğı bulunmuştur (Tablo 3), dolay1sıyla $H_{4}$ desteklenmemiştir.

\section{TARTIŞMA}

$\mathrm{Bu}$ araştırma üniversite hayatının ilk yılındaki gençlerin bu yeni yaşam olayına uyum düzeyleri üzerinde kişilik (DAS/DİS) ve mizah özelliklerinin yordayıcı etkisini incelemeyi amaçlamıştır. Çalışmanın diğer amacı ise DAS/DİS ve uyum ilişkisinde mizah tarzlarının aracı rolünü incelemektir. Çalışma kişilik özelliklerinden DİS'in uyumu negatif, DAS’’n ise pozitif yönde yordadığını göstermiştir. Ayrıca mizah tarzlarından kendini geliştirici ve katılımcı mizah üniversiteye uyumu pozitif yönde yordarken, kendini yıkıcı mizah negatif yönde yordamaktadır. Aracılık modelleri ise genel olarak hipotezlerle tutarlılık göstermiştir.

Ampirik çalışmalar yüksek düzeyde DİS duyarlılığının sosyal uyum üzerinde bozucu etkisi olduğunu göstermektedir (Knyazev, Wilson ve Slobodskaya, 2008). DİS'in kaçınma motivasyonu ile ilişkili olduğu, DİS duyarlılığg yüksek bireylerin daha kaygılı ve cezaya daha duyarlı bireyler oldukları (Bijttebier ve ark, 2009; Carver ve White, 1994; Heponiemi ve ark., 2003; Meyer ve ark., 2005) göz önüne alındığında, DİS puanları ile üniversiteye uyum arasında negatif ilişki görülmesi kuramsal olarak tutarlı bir bulgudur. Yeni bir ortama, akademik ve sosyal düzene uyum sağlamaya çalışan ve bu yeni yaşam olayını stres artıran bir durum olarak değerlendiren, ceza duyarlılı̆̆ı yüksek bireylerin kendilerini güvende ve oraya ait hissetme düzeylerinin diğerlerine göre daha düşük ola- 
bileceği beklenmektedir. Bu bireylerin kaygı düzeyleri artabilir, olaylara ilişkin değerlendirmelerinde durumu daha riskli değerlendirip uyum sağlayacak davranışları sergilemekte zorluk yaşayabilirler.

Çalışmamızda DAS'ın üniversite uyumunu kolaylaştırdığı bulunmuştur. DAS duyarlılı̆̆ fazla olan bireyler daha çok olumlu deneyim aramakta (Gable, 2006), pozitif yaşam deneyimleri için daha fazla zaman harcamakta (Derryberry ve Reed, 1994) ve olumlu duygusal deneyimlere daha fazla önem vermektedirler (Updegraf, Gable ve Taylor, 2004). Ayrıca ödüle duyarlı kişiler yeni deneyimlere açık, dışa dönük, sosyal olarak uyumlu ve duygusal olarak dengelidir. Dahası bu kişilerin hedefe yönelme güdüleri bu kişileri kararlı ve sorumluluk sahibi yapabilmektedir (Corr ve Cooper, 2016). Feldt ve arkadaşlarının (2011) yapmış oldukları çalışmada dışa dönük bireylerin özellikle sosyal uyum olmak üzere üniversite ortamına daha iyi uyum sağladıkları bulunmuştur.

$\mathrm{Bu}$ araştırma sonucunda üniversite uyumunun kendini yıkıcı mizah tarzı tarafından negatif, kendini geliştirici ve katılımcı mizah tarzları tarafından da pozitif yönde yordandığı tespit edilmiştir. Bu alanda yapılmış olan az sayıdaki çalışma, baş etme yöntemi olarak mizah kullanımının üniversite uyumuna olumlu yönde katkısı olduğunu göstermiştir (Alkan, 2014; Hickman ve Andrews, 2003; Hickman ve Crossland, 2004; Rahat ve İlhan, 2016). Ancak bu çalışmalar mizahı tek boyutlu olarak ele almış olup olumsuz mizah tarzlarının uyum üzerindeki etkisine yönelik bilgi sunmamaktadır. Bu açıdan araştırmamız farklı mizah türlerinin kullanımının üniversite uyumu ile ilişkisini anlamada yeni bir bakış açısı sunmaktadır. Örneğin katılımcı mizaha sahip kişilerin sosyal ilişkilerinin iyi olduğu göz önüne alındığında (Kuiper, 2010), stresli durumlarla sosyal destek edinerek daha kolay baş etmeleri mümkündür (Özdemir ve ark., 2011). Buna karş1lık, kendini yıkıcı mizah tarzının ise daha fazla psikolojik stresle (Yue, Hao ve Goldman, 2010), daha az kişiler arası doyumla (Cann Norman, Welbourne ve Calhoun, 2008) ve daha fazla sosyal reddedilmeyle (Kuiper, Kirsch ve Leite, 2010) ilişkili olduğu dikkat çekmektedir. Bu özelliklerin de üniversiteye uyum sürecini zorlaştırdığı düşünülebilir.

Çalışmamızda ayrıca kişilik özellikleri ile uyum arasındaki ilişkide mizah tarzlarının aracı rolü incelenmiştir. DAS ile üniversite uyumu arasında kendini geliştirici ve katılımcı mizah tarzlarının kısmi aracılık rolü olduğu bulunmuştur. Benzer şekilde Ford ve arkadaşlarının (2014) çalışmasında DAS ve mutluluk ilişkisinde kendini geliştirici mizahın aracı rolü olduğu tespit edilmiştir. DAS duyarlılığı olan bireylerin olumlu sonuç- 
lar elde etmek için olaylar karşısında aktif stratejiler geliştirdikleri göz önüne alındığında (Gable, 2006), bu çalışma bulgularına göre üniversite öğrencileri uyum sürecinde kendini geliştirici ve katılımcı mizah kullanarak sürecin daha işlevsel yürütülmesini sağlamaktadır. Ödüle duyarlı kişiler hem eğlenceli uyaranları daha fazla fark ettikleri hem de sosyal ilişkiler kurma eğiliminde oldukları için olumlu mizah tarzlarını kullanarak stresli durumlarla baş edebildikleri gibi aynı zamanda sosyal ilişkilerini de geliştirdikleri düşünülmektedir.

$\mathrm{Bu}$ araştırmada DİS ile üniversiteye uyum arasında kendini yıkıcı mizah tarzının aracı rolü olduğu öngörülmüş, ancak istatistiksel bulgular bu hipotezi desteklememiştir (H4). Gable (2006) ödül duyarlılığı yüksek olan bireylerin olumlu duygusal deneyim elde etmek için aktif girişimlerde bulunmalarına karşın ceza duyarlılığı yüksek olan bireylerin aktif bir biçimde etkisiz ve zararlı yollara başvurmadıklarını ileri sürmektedir. Ancak ceza duyarlılığı yüksek olan bu kişiler zorlayıcı olaylara daha fazla olumsuz duygusal tepkiler vermektedir. Böylece ceza duyarlılığı yüksek olan bireyler uyum sürecinde yaşadıkları zorluklar karşısında daha fazla zorlansalar da, bu durumun her zaman olumsuz baş etme yöntemlerini kullanmalarından kaynaklanmadığı düşünülmektedir (Gable, 2006).

$\mathrm{Bu}$ çalışmanın kesitsel araştırma deseni nedensel çıkarım yapmayı güçleştirmektedir. Özellikle mizah kullanımının stresli durumlarla baş etmedeki etkisi boylamsal yaklaşımlarla incelenmelidir. İleriki çalışmalarda dikkat edilmesi gereken önemli bir nokta da mizah tarzlarını çalışırken öz bildirim ölçeklerine alternatif yolların test edilmesidir. Çünkü öz bildirim ölçeklerinde verilen yanıtların günlük yaşam deneyimleriyle ne ölçüde örtüştüğü belirsizdir. Bu sebepten örneğin; günlük tutulan çalışmalarla (daily diary study) veya deneyim örnekleme yöntemi (experience sampling method) ile kişilerin gün içinde yaşamış olduğu durumlarda ne gibi bir mizahi yaklaşım gösterdikleri daha ayrıntılı incelenebilir.

Çalışmamızdaki bir diğer sınırlılık kullanılan ölçeklerin faktörlerinin güvenirlikleri ile ilişkilidir. Örneğin, Üniversite Yaşamı Ölçeği'nin karşı cinsle ilişkiler, akademik uyum ve sosyal uyum faktörleri ile Mizah Tarzları Ölçeği’nin saldırgan mizah tarzı faktörünün güvenirlik katsayıları yeterli düzeyde bulunmadığı için Üniversite Yaşamı Ölçeği toplam puan üzerinden hesaplanmış ve saldırgan mizah tarzı araştırma modeline dahil edilmemiştir. Ayrıca DAS toplam puan üzerinden ele alınmış olup dürtü, ödüle duyarlılık ve eğlence arayışı faktörleri modelde ayrı ayrı ele alınmamıştır. Ödül duyarlılığı boyutlarının bazılarının aşırı düzeyde olması (örn., eğlence arayışı) uyumdan çok 
davranışsal problemlerle ilişkili olabilmektedir. İleride yapılacak çalışmalarda bu noktaların dikkate alınmasıyla kişilik özellikleri ve uyum süreci daha iyi anlaşılabilir.

Bu çalışmada olumlu bir mizah tarzı olan katılımcı mizah ile DİS arasında pozitif bir ilişki olduğu görülmüştür. Bu bulgu, bazı baş etme becerilerinin kişilik özelliğinin zorunlu bir sonucu olmadığına, aksine olumsuz duyguları deneyimlemeye yatkın kişilerin de olumlu baş etme ve mizah tarzlarını kullanabildiklerine işaret etmektedir. Litman (2006) DİS'in olumsuz baş etme stratejilerinin küçük bir kısmıyla ilişkili olduğunu ve buna karşılık sosyal destek arama ve ilişki kurmayla pozitif yönde ilişkili olduğunu bulmuştur. Böylece ceza duyarlılığı yüksek olan ancak katılımcı mizah kullanan kişilerin bu durumdan fayda görüp görmeyeceği sorusu ileri çalışmalarda ele alınabilir.

Üniversiteye uyum ülkemizde her yıl yaklaşık bir milyon genci etkileyen bir konudur. Bu çalışma biyolojik kişilik özellikleri ve mizah tarzlarının üniversite uyumu üzerindeki etkisini inceleyen ilk çalışma olma özelliği taşımaktadır. Kendini geliştirici ve katılımcı mizahın üniversite uyumunu kolaylaştırıcı rolü olduğu görülmüştür. DİS kişilik özelliğinin de üniversite uyumu için risk oluşturabileceği bulunmuştur. Ancak mizah tarzlarının kişilik özelliklerinden bağımsız olarak üniversite uyumu üzerinde etkisi bulunmaktadır. Araştırmalar mizahın geliştirilebilir bir özellik olduğuna ve düzenlenecek eğitimlerle olumlu sonuçlar alınabileceğine işaret etmektedir (Ruch ve McGhee, 2014).

Buna dayanarak gerek danışmanlık hizmetlerinde gerekse üniversitelerin, yeni başlayan öğrencilerine yönelik düzenledikleri oryantasyon programlarında mizah eğitimine yer vererek, öğrencilerin uyum süreçlerinde karşılaşabilecekleri olumsuzluklarla baş etmelerine yardımcı olabilecekleri düşünülebilir. Bu konuda geliştirilmiş olan Yedi Mizah Alışkanlığı Programı (7 Humor Habits Program) gibi uygulamaların (Ruch ve McGhee, 2014) tamamı ya da bir bölümünden yararlanılarak bilişsel ve davranışçı uygulamalar oryantasyon programlarına entegre edilebilir.

\footnotetext{
Hakem Değerlendirmesi: Dış bağımsız.

Çıkar Çatışması: Yazarlar çıkar çatışması bildirmemiştir.

Finansal Destek: Yazarlar bu çalışma için finansal destek almadığını beyan etmiştir.

Peer-review: Externally peer-reviewed.

Conflict of Interest: The authors have no conflict of interest to declare.

Grant Support: The authors declared that this study has received no financial support.
} 


\section{Kaynakça/References}

Akdur, S. ve Durak-Batıgün, A. D. (2017). Mizah tarzları ile kişilik özellikleri, kişilerarası ilişki tarzları ve psikolojik sağlık arasındaki ilişkiler. Türk Psikoloji Yazıları, 20(39), 1-10.

Akhunlar Turgut, M. N., Sarıot Ertürk, Ö., Karslı, F. ve Şakiroğlu, M. (2018). Algılanan stres ve üniversite yaşamına uyum ilişkisinde bir aracı değişken: Ayrılık anksiyetesi. Hacettepe Üniversitesi Eğitim Fakültesi Dergisi. doi: 10.16986/HUJE.2018044072

Aladă̆ Bayrak, Ö. ve Bülbül, T. (2013). Meslek yüksekokulu öğrencilerinin yükseköğretim yaşamına uyum düzeylerinin çeşitli değişkenlere göre incelenmesi. Sakarya Üniversitesi Eğitim Dergisi, 3(2), 6-20.

Aladağ, M., Kağnıc1, D. Y., Tuna, M. E. ve Tezer, E. (2003). Üniversite yaşamı ölçeği: Ölçek geliştirme ve yapı geçerliliği üzerine bir çalışma. Türk Psikolojik Danışma ve Rehberlik Dergisi, 2(20), 41-47.

Alkan, N. (2014). Humor, loneliness and acceptance: Predictors of university drop-out intentions. Procedia-Social and Behavioral Sciences, 152, 1079-1086.

Aydın, G. (1993). İç-dış kontrol odağı inancı ile durumluk mizah tepkisi arasındaki ilişki. II. Ulusal Psikolojik Danı̧̧ma ve Rehberlik Kongresi Bilimsel Çalışmaları (s. 87-98). Ankara: Hacettepe Üniversitesi.

Baker, R. W. ve Siryk, B. (1984). Measuring adjustment to college. Journal of Counseling Psychology, 31, 179-189.

Barlow, D. H., Sauer-Zavala, S., Carl, J. R., Bullis, J. R. ve Ellard, K. K. (2014). The nature, diagnosis, and treatment of neuroticism: Back to the future. Clinical Psychological Science, 2(3), 344-365.

Besser, A. ve Zeigler-Hill, V. (2011). Pathological forms of narcissism and perceived stress during the transition to the university: The mediating role of humor styles. International Journal of Stress Management, 18(3), 197-221. doi: 10.1037/a0024826

Beyaz, Ş. (2004). Heyecan Arama Gereksinimi ve Akran Baskısının Ergenlerin Risk Alma Eğilimleriyle İlişkisi. (Yayınlanmamış Yüksek Lisans Tezi). Ankara Üniversitesi Eğitim Bilimleri Enstitüsü, Ankara.

Bijttebier, P., Beck, I., Claes, L. ve Vandereycken, W. (2009). Gray's reinforcement sensitivity theory as a framework for research on personality-psychopathology associations. Clinical Psychology Review, 29(5), 421-430.

Cann, A., Norman, M. A., Welbourne, J. L. ve Calhoun, L. G. (2008). Attachment styles, conflict styles and humour styles: Interrelationships and associations with relationship satisfaction. European Journal of Personality, 22, 131-146. doi:10.1002/per.666

Cann, A., Zapata, C. L. ve Davis, H. B. (2011). Humor styles and relationship satisfaction in dating couples: Perceived versus self-reported humor styles as predictors of satisfaction. Humor: International Journal of Humor Research, 24(1), 1-20.

Carver, C. S. ve Connor-Smith, J. (2010). Personality and coping. Annual Review Of Psychology, 61, 679-704.

Carver, C. S. ve White, T. L. (1994). Behavioral inhibition, behavioral activation, and affective responses to impending reward and punishment: The BIS/BAS Scales. Journal of Personality and Social Psychology, 67(2), 319.

Ceyhan, A. A. (2006). An investigations of adjustment levels of Turkish university students with respect to perceived communications skill levels. Social Behavior and Personality, 34(4), 367-380.

Corr, P. J. (2004). Reinforcement sensitivity theory and personality. Neuroscience \& Biobehavioral Reviews, 28(3), 317-332. doi: 10.1016/j.neubiorev.2004.01.005

Corr, P. J. ve Cooper, A. J. (2016). The Reinforcement Sensitivity Theory of Personality Questionnaire (RST-PQ): Development and validation. Psychological Assessment, 28(11), 1427-1440. 
Credé, M. ve Niehorster, S. (2012). Adjustment to college as measured by the student adaptation to college questionnaire: A quantitative review of its structure and relationships with correlates and consequences. Educational Psychology Review, 24(1), 133-165. Doi: 10.1007/s10648-011-9184-5M

Demirci, M. K. (2019). Evli bireylerin öznel iyi oluş düzeyleri ile mizah tarzlarl, temel psikolojik ihtiyaçların doyumu ve evlilik uyumu arasındaki ilişkilerin değerlendirilmesi. (Yayınlanmamış Doktora Tezi). Trabzon Üniversitesi/Lisansüstü Eğitim Enstitüsü, Trabzon.

Derryberry, D. ve Reed, M. A. (1994). Temperament and attention: Orienting toward and away from positive and negative signals. Journal of Personality and Social Psychology, 66, 1128-1139.

Dumanlı, Ş. ve Köroğlu, Ö. (2018). Turist rehberlerinin stresle başa çıkma tarzları ile mizah tarzları arasındaki ilişkinin belirlenmesi. Journal of Yasar University, 13(52), 328-342.

Duru, E. (2016). Üniversiteye uyum sürecinde yalnızlığı yordamada sosyal destek ve sosyal bağl1lı̆̆n doğrudan ve dolaylı rolleri. Türk Psikolojik Danışma ve Rehberlik Dergisi, 3(29) 13-24.

Dyson, R. ve Renk, K. (2006). Freshmen adaptation to university life: Depressive symptoms, stress, and coping. Journal of Clinical Psychology, 62(10), 1231-1244.

Eysenck, H. J. (1967). The biological basis of personality. Springfield, IL: Thomas.Feldt, R. C., Graham, M. ve Dew, D. (2011). Measuring adjustment to college: Construct validity of the student adaptation to college questionnaire. Measurement and Evaluation in Counseling and Development, 44(2), 92-104.

Ford, T. E., Lappi, S. K. ve Holden, C. J. (2016). Personality, humor styles and happiness: Happy people have positive humor styles. Europe's Journal of Psychology, 12(3), 320-337.

Ford, T. E., McCreight, K. A. ve Richardson, K. (2014). Affective style, humor styles and happiness. Europe's Journal of Psychology, 10(3), 451-463.

Franken, I. H. ve Muris, P. (2006). BIS/BAS personality characteristics and college students' substance use. Personality and Individual Differences, 40(7), 1497-1503.

Fritz, H. L., Russek, L. N. ve Dillon, M. M. (2017). Humor use moderates the relation of stressful life events with psychological distress. Personality and Social Psychology Bulletin, 43(6), 845-859.

Gable, S. L. (2006). Approach and avoidance social motives and goals. Journal of Personality, 74(1), $175-222$.

Gallagher, D. J. (1996). Personality, coping, and objective outcomes: Extraversion, neuroticism, coping styles, and academic performance. Personality and Individual Differences, 21(3), 421-429.

Gray, J. A. (1982). The neuropsychology of anxiety: An enquiry into the function of the septohippocampal system. New York: Oxford University Press.

Gray, J. A. (1990). Brain systems that mediate both emotion and cognition. Cognition and Emotion, 4(3), 269-288.

Hayes, A. F. (2016). Process 2.16.1 [Bilgisayar program1]. Erişim Adresi: http://www.processmacro. org/download.html

Heponiemi, T., Keltikangas-Järvinen, L., Puttonen, S. ve Ravaja, N. (2003). BIS/BAS sensitivity and self-rated affects during experimentally induced stress. Personality and Individual Differences, 34(6), 943-957.

Hickman, G. P. ve Andrews, D. (2003). Humor and college adjustment: The predictive nature of humor, academic achievement, authoritative parenting styles on the initial adjustment of male and female firstyear college students. Journal of The First-Year Experience \& Students in Transition, 15(2), 61-81.

Hickman, G. P. ve Crossland, G. L. (2004). The predictive nature of humor, authoritative parenting style, and academic achievement on indices of initial adjustment and commitment to college among college freshmen. Journal of College Student Retention: Research, Theory \& Practice, 6(2), 225-245. 
Hundt, N. E., Kimbrel, N. A., Mitchell, J. T. ve Nelson-Gray, R. O. (2008). High BAS, but not low BIS, predicts externalizing symptoms in adults. Personality and Individual Differences, 44(3), 565-575.

İkiz, F. E. ve Otlu, B. M. (2015). Üniversite yaşamına uyum sürecinde yaşanan sorunlar ve başa çıkma yolları. Celal Bayar Üniversitesi Sosyal Bilimler Dergisi, 13(4) 35-52. doi: 10.18026/cbusos.93556

Jorm, A. F., Christensen, H., Henderson, A. S., Jacomb, P. A., Korten, A. E. ve Rodgers, B. (1998). Using the BIS/BAS scales to measure behavioural inhibition and behavioural activation: Factor structure, validity and norms in a large community sample. Personality and Individual Differences, 26(1), 49-58.

Kaba, İ. ve Keklik, İ. (2016). Öğrencilerin üniversiteye uyumlarında psikolojik dayanıklılık ve psikolojik belirtiler. Hacettepe Eğitim Araştırmaları Dergisi, 2(2) 98-113.

Karahan, F., Sardoğan, M. E., Özkamalı, E. ve Dicle, A. N. (2005). Üniversite 1. sınıf öğrencilerinin üniversiteye uyum düzeylerinin sosyokültürel etkinlikler açısından incelenmesi. Çukurova Üniversitesi Ĕgitim Fakültesi Dergisi, 2(30), 63-72.

Korotkov, D. ve Hannah, T. E. (1994). Extraversion and emotionality as proposed superordinate stress moderators: A prospective analysis. Personality and Individual Differences, 16, 787-792.

Kuiper, N. A. (2010). Introductory comments: Special issue of EJOP on humor research in personality and social psychology (editorial). Europe's Journal of Psychology, 6, 1-8.

Kuiper, N. A., Kirsh, G. A. ve Leite, C. (2010). Reactions to humorous comments and implicit theories of humor styles. Europe's Journal of Psychology, 6(3), 236-266. doi:10.5964/ejop.v6i3.215.

Knyazev, G. G., Wilson, G. D. ve Slobodskaya, H. R. (2008). Behavioural activation and inhibition in social adjustment. P.J. Corr (Ed.), The reinforcement sensitivity theory of personality içinde (s. 415430). New York: Cambridge University Press.

Lazarus, R. S. ve Folkman, S. (1984). Stress, appraisal, and coping. New York: Springer.

Litman, J. A. (2006). The COPE inventory: Dimensionality and relationships with approach- and avoidance-motives and positive and negative traits. Personality and Individual differences, 41(2), 273-284. doi: 10.1016/j.paid.2005.11.032

Lu, L. (1994). University transition: Major and minor life stressors, personality characteristics and mental health. Psychological medicine, 24(1), 81-87.

Mardaga, S. ve Hansenne, M. (2007). Relationships between Cloninger's biosocial model of personality and the behavioral inhibition/approach systems (BIS/BAS). Personality and Individual Differences, 42(4), 715-722.

Martin, R.A. (2001). Humor, laughter, and physical health: Methodological issues and research findings. Psychological Bulletin, 127, 504-519.

Martin, R. A., Kuiper, N. A., Olinger, L. J. ve Dance, K. A. (1993). Humor, coping with stress, selfconcept, and psychological well-being. Humor, 6, 89-89.

Martin, R.A. ve Lefcourt, H. M. (1983). Sense of humor as a moderator of the relation between stressors and moods. Journal of Personality and Social Psychology, 45, 1313-1324.

Martin, R. A., Puhlik-Doris, P., Larsen, G., Gray, J. ve Weir, K. (2003). Individual differences in uses of humor and their relation to psychological well-being: Development of the humor styles questionnaire. Journal of Research in Personality, 37(1), 48-75.

McCrae, R. R. ve Costa, P. T. (2003). Personality in adulthood: A five-factor theory perspective (2nd ed.). Guilford Press.

Meyer, B., Olivier, L. ve Roth, D. A. (2005). Please don't leave me! BIS/BAS, attachment styles, and responses to a relationship threat. Personality and Individual Differences, 38(1), 151-162.

Overholser, J. C. (1992). Sense of humor when coping with life stress. Personality and Individual Differences, 13(7), 799-804. 
Overholser, J. C. ve Adams, D. M. (1997). Stressful life events and social support in depressed psychiatric inpatients. T.W. Miller (Ed.), Clinical disorders and stressful life events içinde (s. 121141). Connecticut: International Universities Press.

Özbay, Y., Palancı, M., Kandemir, M. ve Çakır, O. (2012). Üniversite öğrencilerinin öznel iyi oluşlarının duygusal düzenleme, mizah, sosyal öz-yeterlilik ve başa çıkma davranışları ile yordanması. Türk Eğitim Bilimleri Dergisi 10(2), 325-345.

Özdemir, S., Sezgin, F., Kaya, Z ve Recepoğlu, E. (2011). İlköğretim okulu öğretmenlerinin stresle başa çıkma tarzları ile kullandıkları mizah tarzları arasındaki ilişki. Kuram ve Uygulamada Eğitim Yönetimi Dergisi, 17(3), 405-428.

Plessen, C. Y., Franken, F. R., Ster, C., Schmid, R. R., Wolfmayr, C., Mayer, A. M., ... Maierwieser, R. J. (2020). Humor styles and personality: A systematic review and meta-analysis on the relations between humor styles and the Big Five personality traits. Personality and Individual Differences, 154. doi: 10.1016/j.paid.2019.109676

Porterfield A. I. (1987). Does sense of humor moderate the impact of life stress on psychological and physical well-being? Journal of Research in Personality, 21, 306-317.

Pritchard, M. E., Wilson, G. S. ve Yamnitz, B. (2007). What predicts adjustment among college students? A longitudinal panel study. Journal of American College Health, 56(1), 15-22.

Rahat, E. ve İlhan, T. (2016). Coping styles, social support, relational self-construal, and resilience in predicting students' adjustment to university life. Educational Sciences: Theory \& Practice, 16, 187-208.

Rasmussen, S. A., Elliott, M. A. ve O'Connor, R. C. (2012). Psychological distress and perfectionism in recent suicide attempters: The role of behavioural inhibition and activation. Personality and Individual Differences, 52(6), 680-685.

Reisoğlu, S. ve Yazici, H., (2017). The role of university students' five factor personality traits, humorstyles, and emotional intelligence on their interpretation of subjective well-being. Journal of History Culture and Art Research, 6(4), 888-912. doi: 10.7596/taksad.v6i4.973

Romundstad, S., Svebak, S., Holen, A. ve Holmen, J. (2016). A 15-year follow-up study of sense of humor and causes of mortality: The Nord-Trondelag health study. Psychosomatic Medicine, 78, 345-353.

Rosenman, S. ve Rodgers, B. (2006). Childhood adversity and adult personality. Australian and New Zealand Journal of Psychiatry, 40(5), 482-490.

Ruch, W. ve McGhee, P. E. (2014). Humor intervention programs. A.C. Parks ve S.M. Schueller (Ed.), The Wiley-Blackwell handbook of positive psychological interventions içinde (s. 179-189). New Jersey: Wiley-Blackwell.

Safranek, R. ve Schill, T. (1982). Coping with stress: Does humor help? Psychological Reports, 51, 222.

Sobel, M. E. (1982). Asymptotic confidence intervals for indirect effects in structural equation models. Sociological Methodology, 13, 290-312.

Şişman, S. (2012). Davranışsal Inhibisyon Sistemi/Davranışsal Aktivasyon Sistemi Ölçeği’nin Türkçe’ye uyarlanması: Geçerlik ve güvenirlik çalışması. Psikoloji Çalışmaları Dergisi, 32(2), 1-22.

Tuna, M. E. (2003). Cross-cultural differences in coping strategies as predictors of university adjustment of Turkish and U.S. students. (Yayınlanmamış Doktora Tezi). Middle East Technical University, Ankara, Turkey.

Türkiye İstatistik Kurumu. (2019, Haziran). Yükseköğretim İstatistikleri. Erişim Adresi https://istatistik. yok.gov.tr 
Updegraff, J. A., Gable, S. L. ve Taylor, S. E. (2004). What makes experiences satisfying? The interaction of approach-avoidance motivations and emotions in well-being. Journal of Personality and Social Psychology, 86(3), 496-504.

Vella-Zarb, R. A. ve Elgar, F. J. (2010). Predicting the 'freshman 15': Environmental and psychological predictors of weight gain in first-year university students. Health Education Journal, 69(3), 321332.

Vervoort, L., Wolters, L. H., Hogendoorn, S. M., De Haan, E., Boer, F. ve Prins, P. J. (2010). Sensitivity of Gray's behavioral inhibition system in clinically anxious and non-anxious children and adolescents. Personality and Individual Differences, 48(5), 629-633.

Viana, A. G. ve Gratz, K. L. (2012). The role of anxiety sensitivity, behavioral inhibition, and cognitive biases in anxiety symptoms: Structural equation modeling of direct and indirect pathways. Journal of Clinical Psychology, 68(10), 1122-1141.

Vilaythong, A.P., Arnau, R. C., Hosem, D. R. ve Mascaro, N. (2003). Humor and hope: Can humor increase hope? Humor, 16(1), 79-89.

Voigt, D. C., Dillard, J. P., Braddock, K. H., Anderson, J. W., Sopory, P. ve Stephenson, M. T. (2009). BIS/BAS scales and their relationship to risky health behaviours. Personality and Individual Differences, 47(2), 89-93.

Warbah, L., Sathiyaseelan, M., Vijayakumar, C., Vasantharaj, B., Russell, S. ve Jacob, K. S. (2007). Psychological distress, personality, and adjustment among nursing students. Nurse education today, 27(6), 597-601.

Yalım, D. (2007). First year college adjustment: The role of coping, ego-resiliency, optimism and gender. (Yayınlanmamış Doktora Tezi). Middle East Technical University, The Graduate School of Social Sciences, Ankara.

Yerlikaya, E. (2003). Mizah tarzları ölçeğinin uyarlama çalışması. (Yayınlanmamış Yüksek Lisans Tezi). Sosyal Bilimler Enstitüsü, Çukurova Üniversitesi, Adana, Türkiye.

Yıldız, A. D. (2018). Erken dönem uyum bozucu şemalar ve yalnızlığın üniversite uyum düzeyi ile ilişkisi. Türk Psikoloji Dergisi, 33(81), 82-96.

Yue, X., Hao, X. ve Goldman, G. (2010). Humor styles, dispositional optimism, and mental health among undergraduates in Hong Kong and China. Journal of Psychology in Chinese Societies, 11, 173-188. 
